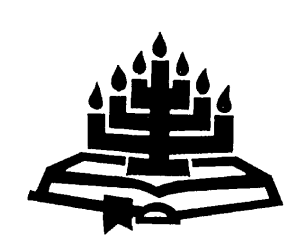

\title{
Living wisely in a modern world'
}

\section{Steyn}

Department of Biblical and Religious Studies

Faculty of Humanities

University of Pretoria

PRETORIA

Email: Iynettesteyn@webmail.co.za

\section{Abstract}

\section{Living wisely in a modern world}

People all over the world today have to compete for their daily bread and struggle to make ends meet. This represents the arena where humans battle to cope with the complexities of daily life. At the same time they try to find meaning in life and guidelines to live life well. It is here, in ordinary real life, where wisdom and folly compete for human loyalties and where the divine and the human meet (O'Connor, 1993:14). It is here where Proverbs 3 gives us diverse guidelines on how to live wisely in a modern world.

\section{Opsomming}

\section{Lewe wys in 'n moderne wêreld}

Die meeste mense leef met die las van daaglikse pligte, om kos op die tafel te hou, rekenings te betaal en om getrou aan al die vereistes van werk en liefde te voldoen. Regoor die wêreld sukkel mense om genoeg te verdien om te kan oorleef. Hierdie stryd verteenwoordig die arena waarin die mensdom veg om die kompleksiteite van hulle daaglikse lewe te kan hanteer. Terselfdertyd poog die mens om betekenis en sin in die lewe te vind en om riglyne daar te stel waarvolgens hulle goed kan lewe. Dit is hier, in die gewone alledaagse lewe, waar wysheid en dwaasheid wedywer om die mens se lojaliteit te wen. Dit is hier waar die bonatuurlike en die menslike ontmoet (O'Connor, 1993:14). Spreuke 3 gee talle riglyne waarvolgens die mens met wysheid in 'n moderne era kan lewe.

1 This article is the outcome of an M.A. dissertation under the supervision of Prof. Dirk Human, Department of Old Testament Studies at the University of Pretoria. 


\section{Introduction}

Wisdom guides humanity in how to live in the world, and it understands that the arena where God comes to meet people is daily life. Wisdom literature, having a specific perspective on life that sees God as the Creator of order and the world, focuses on life and the world $^{2}$ and not on revelation or the history of salvation. For this reason, all wisdom is intrinsically religious, though human experience is the place where it is learnt. Throughout the biblical texts the Hebrew and Greek nouns for wisdom, hokmah and Sophia, refer to a way of thinking, a way of living, a body of literature, various technical skills, a search for meaning and order, common sense about life and human relations, reverent "fear of the Lord" and a woman, personified wisdom herself (O'Connor, 1993:23). As in biblical times, people today still search for meaning of life and guidelines to live life well.

Traditionally, the Book of Proverbs is seen as the book of wisdom par excellence, covering a vast diversity of subjects transcending time. Being part of the wisdom literature, it is widely accepted that the admonitions in the Book of Proverbs were embedded in the everyday life of the Yahweh assembly and were seldom separated from their religion (Perdue, 2000:100).

\section{Life problems}

Peck (1978:13), a practicing psychiatrist and writer, states that "Life is difficult", but that once people truly see and grasp this truth, it can be transcended.

Life problems call for our courage and wisdom and for this reason wise people learn not to dread, but to actually welcome the challenges of real life. In doing so, the wise choose to believe that problems and challenges are the cutting edge that distinguishes between living life as a wise man or as a fool.

Through experience of working closely with people of different age groups, different social status and different backgrounds for the past 27 years, I have found that people could be very well educated, successful in their different careers, financially successful and also academically successful. Yet they are still seeking for something more in life which I call "a search for meaning".

$2 \quad$ World in this context means nature and humanity. 
In South Africa we face corruption, rape (150,4 per day) and murder (50,8 per day) in a high degree (Anon., 2006b:5). Violence, assaults and residential robberies are not strange and according to Safety and Security Minister Charles Nqakula, "a large chunk of South African crime is happening between people who know each other" (Anon., 2006b:3).

Looking at these situations, it could be concluded that conditions such as crime, abuse, poverty, corruption and murder are primarily the result of a very deeply rooted, more serious problem and surely does not speak of "wholeness" of life. It is my suggestion that these problems together with a search for the meaning of life call for people's courage and their wisdom to live life happily.

\section{Happiness and behaviour}

Le Roux (2006:2) stated that according to the ancient Israelite sages, living life wisely and having happy relationships, are direct results of a specific pattern of behaviour. Wisdom theology seems to capture the fact that there is a link between happiness and behaviour. Follow the principles of truths learnt by life experienced, bound to a perspective of "fear of God", and you will be happy (Johnson, 1975:10). The wisdom philosophy that is been held onto, emphasises that humankind has the ability to work out his/her own happiness and find meaning in life, if and when, the "fear of God" is the beginning of all their actions (Prov. 1:7; 3:7).

Conflicting to the perspective of Old Testament wisdom that "fearing God is the beginning of all wisdom", is a modern life perspective of a one-dimensional, "man on an island"-being that keeps a "mental distance" from others (Peck, 1993:30). God does not play a role in any decision-making. Supporting this statement is the statistics produced by Barna (2006:25), in which more than two thirds of all American Christian adults do not agree that success is determined by their measure of obedience to God.

Wisdom as seen in the Book of Proverbs, gives an optimistic view on mankind and a confidence that the human intellect and rationale can achieve something meaningful (Cox, 1982:92). It shows us humanity wrestling with challenges still faced today, but at the same time Proverbs 3 supplies ample guidelines for living well. It teaches people how to live and work in the world yet at the same time acknowledging God as creator and trusting in his guidance and ordering of the world (Whybray, 1972:13). 


\section{Patterns of behaviour}

The approach to life that brings about wise living is twofold. On the one hand God is to be recognised as the beginning of all wise living. On the other hand specific patterns of behaviour are to be followed in order to live a happy life. This implies that wisdom has a religious and an intellectual aspect and that human knowledge and divine control are not mutually exclusive according to Le Roux (Deist \& Vorster, 1986:109).

The "fear of God" (Prov. 1:7) is the cornerstone of an approach to life and accepted as a pattern of behaviour. This life of fearing God is about repentance, new life and wholeness. In Proverbs 3:7 the father teaches his son to turn away from evil, that is, to repent of his wrong ways and to fear God. In doing so it will bring new life (healing) and refreshment (wholeness) to his bones and this wholeness implies his entire life (Garrett, 1993:79).

The purpose of this discourse is not to provide simplistic answers, but rather to suggest guidelines and the means to choose between wisdom ${ }^{3}$ and folly. 4

\section{Context of the Book of Proverbs}

To appreciate the relation of the Book of Proverbs to the wisdom literature of ancient Israel, it is to be contextually analysed. A consideration of the historical, social and cultural context as well as the relation of Proverbs to wisdom literature in the ancient East, specifically that of Egypt and Mesopotamia, and the origin and date of the book has been included.

In the formal analysis of the text, the literary forms include a variety of sayings such as the proverb, question and riddle, numerical saying, beatitude, admonition and prohibition as well as instructions, dialogues, didactic narratives and poems (Perdue, 2000:5).

Literature reviewed for this study includes the work of specialist biblical scholars such as Crenshaw (1981), Loader (1986), and

3 Wisdom has several dimensions such as moral discernment, skill, cleverness, and intellectual knowledge. When this moral quality of wisdom is combined with the concept of reverence for the Lord, wisdom has fully flowered (Johnson, 1975:9).

$4 \quad$ Folly is the total opposite of wisdom. 
Whybray (1995) who explored the background, origin and meaning of the Old-Testament wisdom over many years. The study further included scholars commenting on Proverbs 3 such as McKane (1970), Garret (1993), Harris (1995) and Perdue (2000).

\section{Hypothesis}

The wisdom philosophy calls for a deep reverence for God in conforming one's life to the Creator's design and order in the midst of a life full of challenges and therefore "the end of all wisdom is to know God" (Peck, 1985:118).

At the same time humankind yearns for guidance in living and for a life where belief, attitude, affections and action form an interrelated unity which gives meaning to their lives (O'Connor, 1993:9).

With these challenges of humanity in mind, the following hypothesis for wise living is suggested from the analysis of Proverbs 3.

- In a broken community and especially in a believing community, biblical wisdom poses an ingredient for harmonious relationship between God and humankind, and between humans.

- For religious believers God is the source of wisdom and order in life.

- Biblical wisdom needs to be decided upon by the individual or community and, therefore, requires a conscious decision to firstly remember what has been taught in biblical wisdom and secondly to exercise the art of wise living thereof.

- Biblical wisdom requires responsibility to live wisely among fellow humans in order to display harmonious living.

\section{Conforming to a life of wise living according to a divine order}

To learn from experience implies that experience must be passed on by generations. In ancient Israel the sages left a valuable legacy to the world in the form of wisdom literature which started off with the belief that the world was essentially ordered and good (Cox, 1982: 12). Inherent to the nature of things was a divine order that could be comprehended by human effort. It is, therefore, possible for man to become wise, take responsibility for and achieve proficiency over creation, while ultimately remembering that God is the controller of creation (Cox, 1982:13). 
From a religious perspective, the person who has found his/her place in the created world 5 and has a relationship with God as Creator, will in all probability live a fulfilled life. Such a person will be wise $^{6}$ and will be distinguished by a specific attitude of kindness, graciousness and pleasantness. This is contrasted to the fool who, according to Qoheleth (10:12-15), ${ }^{7}$ gossips, has no discipline of mind or tongue and uses wicked words. Wisdom and folly continuously stand directly opposite to each other, for the "fool" is the negative of the "wise". A person who is foolish lacks the mastery of human environment and disregards any form of teaching.

\section{Wisdom as a philosophy of living}

The philosophy of life in Israelite wisdom is that God is Creator, both of his people and the physical world; all knowledge and wisdom come from God. The sages observed an order of justice and blessing that provided for the continuation of the existence of both human and non-human creatures. The goal is to live in harmonious relationship with God, others and the world, while understanding that creation was not a "once-for-all event locked in the primordial past, but rather a continuous action" (Perdue, 1994:79).

Because wisdom has a concept of "goodness", it has a social dimension which is ultimately observed in relationships. The reality of relationship with wisdom determines how one should act in any given situation (Cox, 1982:61). It is not a code of laws or commandments, but a relationship to the society and the world in which God has placed a person.

Wisdom is, therefore, concerned with the issues facing humanity in general. In its broadest sense, wisdom is an approach to reality. It is a philosophy which shares a set of ideas, assumptions and expectations about life. In the ancient Near East this way of thinking was international in origin and influence.

As a mirror held up to life is the Book of Proverbs. The admonitions and teachings are timeless, in the sense that it is not addressed to any one age or people, but to all ages and every sort of person

5 Living according to a divine order, ma'at.

6 Coordinated and in control of life to the extent that it is possible to be (Cox 1982:15).

$7 \quad$ The preacher and author of Ecclesiastes. 
(Cox, 1982:83). The Book of Proverbs appeals to the most basic things in everyday life and helpful guidelines concerning the world we live in where religious, political or social background is not considered, are given. These teachings are about living well on this earth as a parent, a child, a husband or wife, a citizen and a worker. It is about how to live in relationship with God and one's neighbour whether you are a teacher, an artist or a mother attending to her children.

Trust in the LORD with all your heart, and do not rely on your own insight.

In all your ways acknowledge him, and he will make straight your paths.

Be not wise in your own eyes;

fear the LORD, and turn away from evil. (Prov. 3:5-7.)

Most people are searching for a life filled with good relationships: happy families and contented communities, a life where the environment is safe, peaceful and happy. God the Creator created humankind to live life as the one that will subdue, be fruitful in all they do and have dominion over life in all aspects as stated in Genesis 1:2829.

According to Genesis 1:31 the environment, the light, the night and day, the animals, birds, fishes and humankind was very good and was meant to be good to live in. The creation narrative implies God's purpose for humanity is to be "very good" (Gen. 1:31). This means for people to have good relationships, peace and happiness and live from the perspective and within the guidelines of wisdom. Wisdom exhorts people to search for the meaning of real life that is to be found when God meets people in daily life. One of the main intentions of the Book of Proverbs is to lead people by ways of uprightness, intelligence and religious "backbone" to a fulfilled life (Cox, 1982:92).

In this reflection on wise living it has been found that the wisdom literature of the Old Testament, with specific reference to Proverbs 3 , supplies different guidelines for living well. It holds up a concise picture of guidance for every aspect of wise and sound living.

The art of living seems to be the most difficult of all the arts and there is no simple solution. Fortunately, experience and observations can be shared. Insights can be learned. Wisdom can be taught. For this very reason the guidelines for living a wise life was taught to young future leaders of the nation which gave wisdom an assumed educational role. It is supposed that wisdom schools 
existed in ancient Israel where young men were trained in life skills and specifically in the perspective and philosophy of the Old-Testament wisdom. This process of teaching was important and valuable. Guidelines and laws were taught from one generation to another through parental teaching (Fox, 1996:232). In the present troubled historical and cultural context at the end of the millennium people are asking, as perhaps never before, what wisdom is and where it is to be found (Barton, 1999:xvii).

In South Africa corruption, violence, assaults and residential robberies are part of everyday life and the question is constantly being asked: how do I live a happy life? Rauch (2005:1) made the statement:

Politicians, religious leaders and social commentators have all spoken about a breakdown in morality in South Africa, with crime as the most commonly cited evidence.

With many political and economical changes in South Africa in the past decade, it is understandable that Bishop Desmond Tutu (2006: 1) asked the question:

What has happened to us? It seems as if we have perverted our freedom, our rights into license, into being irresponsible.

Rights go hand in hand with responsibility, with dignity, with respect for oneself and the other.

It is in everyday real life when respect, integrity and care for others are absent, that wisdom and folly compete for human loyalties and where the divine and the human meet (O'Connor, 1993:14).

Humanity is seeking for an integrated life of faith in which belief, attitude, affections, prayer and action form a cohesive unity which will give meaning to their lives (O'Connor, 1993:9). In Proverbs 3 a practical and explicit picture of people wrestling with challenges that still face us today is found, as well as guidance for every aspect of wise and sound living. It has not provided us with simplistic answers, but rather has suggested guidelines been found for living wisely in a complex world such as the modern South African context.

\section{Suggested guidelines to wise living}

The wisdom philosophy, which is seated in faith in God as Creator and beginning of all wisdom, emphasises that man has the ability to determine his/her own happiness and then also find meaning in life. According to the ancient Israelite sages, living life wisely and having 
harmonious relationships, are direct results of a specific pattern of behaviour. It is this pattern of behaviour found in Proverbs 3 through this study that has led to become the suggested guidelines to wise living.

\subsection{Wisdom as life ingredient for harmonious relationship between God and humankind and between humans}

In a broken community and especially in a believing community, biblical wisdom poses an ingredient for harmonious relationship between God and humankind, and between humans. Wisdom is personified as a woman and the search to find her is not simply a seeking of the intellect, but also a longing of the human heart which brings about joy together with great and long-lasting material rewards. Upon entering into a relationship with Lady Wisdom, the wise man or woman live in a state of well-being and delight (Perdue, 2000:103) and her paths are characterised by pleasantness.

Wisdom teaches that one of the major guidelines for living life successfully is that of a relationship between God and humankind and between humans. Life on earth is about living with and among others. It is about knowing what to do, how to do it and when to do it. It is about living in harmony with others.

Learning to live life and standing in relationship with others starts between parent and child and, therefore, the Book of Proverbs has to do with the teaching of the youth.

\subsubsection{Relationship between father and son}

In verses 1-4 the father invites the son 8 into a relationship with himself. He invites him to trust his experience and observations concerning true life and urges him to bind them around his neck and write them on his heart so that he will never forget them. The father does not specify any content of his commands, but it may be supposed that they are the basic teaching of chapters 1-9 (Clifford, 1999:51).

These teachings include seeking wisdom first, to hold in the highest regard the teacher's words and to trust God's action. Loyalty and faithfulness towards the father are described by a metaphor in such

8 Probably an idealised reference to all young men and women addressed by the sages (Perdue, 2000:99). 
a way that the son needs to internalise these virtues. Adhering to the father's teaching and being loyal and faithful towards the father, creates a strong and enduring relationship between father and son.

Compliance with the rules of wisdom implies submission to authority (Loader, 1986:110). "My son, do not forget my teaching." (Prov. 3:1.) Here the father, in the light of their relationship, urges his son to:

- recognise and remember him as a symbol of experience of life;

- be humble; and

- participate in God's order for man.

Today the relationship as found in Proverbs 3 between father and son can be between any young person and another person with life experience who are willing to teach and guide the youth in the art of living. On the side of the young he/she has to be willing to be humble and remember and live the experience and teachings of the teacher.

\subsubsection{Relationship between God and humankind}

A relationship between God and humankind is a choice. The father encourages the son to choose God and his order, he is exhorted to choose to "fear the Lord" and turn away from evil (Prov. 3:7). In Proverbs 3:5-12 the father gives his son guidelines on how to live in relationship with God. He explains that certain characteristics have to be present when living in relationship with God. One needs to:

\subsubsection{Trust in the Lord (v. 5)}

Trust in God is a virtue that is central to the practice of religious faith. It means to rely on God's truthfulness and integrity and to know that God will protect the one who lives in a relationship of total trust with God (Perdue, 2000:98). In trusting God he will experience healing to his flesh and refreshment to his bones and will have plenty to eat and to drink.

\subsubsection{Fear and honour the Lord (v. 7, 9)}

In fearing God man acknowledges God as the Creator and Sustainer of this earth and also of his own life. When fearing God he will be practicing the moral life that will not deviate into shallowness and wickedness (Perdue, 2000:98). 


\subsubsection{Adhere to the Lord's discipline (v. 11)}

In relationship with God, reprimandment should not be seen as rebuke, but rather as the guiding hand and caring word of a loving parent towards the child (Perdue, 2000:99). Discipline from the Lord should be understood as a sign of divine paternal love (Murphy, 1998:21) and will be an element of the loving relationship between God and man.

\subsubsection{Remember God's love for his people (v. 12)}

Just as a father reproves his son in whom he delights, the Lord reproves those He loves. There is no mechanical balance sheet notion of retribution or a simple and immediate causal link between sin and retribution (Fox, 2000:152). Such a true relationship between God and man is only displayed when:

- God is recognised as the source of all wisdom and knowledge;

- God is acknowledged as the source of all; and

- divine discipline is accepted as a result of a loving person teaching a student to live wisely.

In conclusion it can be assumed that in all probability the relationship between parent and child is the cornerstone of many relationships. Today this cornerstone relationship can be seen as a portrayal of a loving relationship between two people where the one is older, has life experience and is living a harmonious life while the younger student acknowledges, accepts and adheres to the teacher's guidance and teaching.

Once the young enters into relationship with his father (teacher), the experience and loving guidance of the father will lead the son into relationship with God who is the source of all true knowledge and real life. In man's relationship with God and his earthly father (teacher), he/she will learn to adhere to the order of creation and thus experience material blessings (Murphy, 1998:21).

\subsection{God is the source of all wisdom and order (Prov. 3:19-20)}

"The creator is the divine architect who designs and constructs the cosmos in the form of an elegant and well-planned building or city (Prov. 3:19-20; 8:26-29)." (Perdue, 1994:79.) In this portrait, wisdom is the skill or the plan and knowledge that God uses to secure and order the universe. All wisdom is grounded in the life-giving order of the cosmos created and sustained by God who is the beginning of 
all. People, when guided by God's wisdom attained as a gift from God, have the ability to direct their own lives and to transmit to others the life-sustaining teaching that enables people and communities to persevere.

\subsection{Wisdom requires a wise decision (Prov.3:21)}

This verse refers to "your ability and prudence" (Whybray, 1972:29). The father exhorts his son to keep what he has learnt and to continue searching and studying wisdom throughout his lifetime. It seems that wisdom is, according to the wise men, not guaranteed to be a permanent possession (Perdue, 2000:106). One has to make a decision and then actively hang wisdom around your neck as a charm. This will then be "your source of vitality" (Whybray, 1972:29).

\subsection{Wisdom requires responsibility (Prov. 3:27-32)}

\subsubsection{Open your hand to your neighbour (v. 27-28)}

The father urges his son to give to his neighbour when he is in the position to give. The wisdom tradition never teaches the abandonment of possession in order to follow a life of poverty, but it does stress the importance of supporting those in need. In doing so, the sages were modelling the compassion and charity of Yahweh.

\subsubsection{Do not plan evil (v. 29)}

A responsibility to live at peace with one's neighbour is expected of the man who is living wisely. There is a presupposition that a neighbour has some right to consideration (Murphy, 1998:23) and, therefore, a person has to avoid unjustified legal disputes. ${ }^{9}$

Once wisdom has been attained, specific virtues become part of man's life which include a position of trust before God (v. 32), deliverance from evil people (v. 25), honour (v. 35), long life and riches (v. 2), God's blessings (v. 33), and real life (v. 22).

The principle of God as the source of all wisdom and order in life, forms the cornerstone of the wisdom perspective, and therefore, of harmonious living. Biblical wisdom has to be chosen and therefore needs a conscious decision to firstly remember what has been taught and secondly to exercise the art of biblical wise living. Lastly

9 According to Murphy (1998:23) "such is the meaning of "contend"'. 
wisdom requires responsibility to live wisely among one's fellowmen in order to display harmonious living.

The goal for the individual that seeks meaning in life, for South Africa as a community and the broader world will be to live in harmonious relationship with God, others and the world. In the suggested guidelines in Proverbs 3 answers to questions such as how to live life, how to think, how to cope and how to succeed, is given to every person searching for a meaningful life. Proverbs 3:6 summarises the teaching found in Proverbs 3:

In all thy ways acknowledge him, and he shall direct thy paths.

This teaching exhorts the student to fill his/her life with the essential worth of wisdom and discretion. In doing so he/she will enjoy the comfort and security of God and make wise and meaningful decisions while at the same time receive the protective oversight of God. These virtues will enable man to live in harmony with his/her neighbour and not to envy the "violent".

A healthy organization - whether a marriage, a family, or a business corporation - is not one with an absence of problems, but one that is actively and effectively addressing or healing its problems. (Peck, 1993:10.)

Once wisdom is internalised in man's life, the behaviour of the individual will affect the well-being of the community.

\section{List of references}

ANON. 2006a. Good and bad news as crime figures are finally released. The Star: 3, 28 Sept.

ANON. 2006b. Our children are the ones who suffer. The Star: 5, 30 Sept.

BARNA, G. 2006. The state of the church. www.barna.org Date of access: 8 Sept. 2006.

BARTON, S.C. 1999. Introduction. (In Barton, S.C., ed. Where shall wisdom be found? Wisdom in the Bible, the church and the contemporary world. Edinburgh: Clark. p. xvii-xxiv.)

CLIFFORD, R.J. 1999. Proverbs: a commentary. Louisville: Westminster John Knox.

COX, D. 1982. Proverbs with an introduction to sapiential books. Wilmington: Glazier.

CRENSHAW, J.L. 1981. Old Testament wisdom and introduction. Atlanta: John Knox Press.

DEIST, F.E. \& VORSTER, W.S., eds. 1986. Words from afar. Cape Town: Tafelberg. 
FOX, M.V. 1996. The social location of the Book of Proverbs. Winona Lake: Eisenbrauns.

FOX, M.V. 2000. Proverbs 1-9: a new translation with introduction and commentary. New York: Doubleday.

GARRET, D.A. 1993. The new American commentary: Proverbs, Ecclesiastes, Song of Songs. Nashville: Broadman.

HARRIS, S.L. 1995. Proverbs 1-9: a study of inner-biblical interpretation Georgia: Scholars Press Atlanta.

JOHNSON, L.D. 1975. Israel's wisdom: learn and live. Nashville: Broadman.

LE ROUX, J.H. 2006. The wisdom of Israel. www.otnet.net/sermon Date of access: 28 Sept. 2006.

LOADER, J.A. 1986. Texts with a wisdom perspective. (In Deist, F.E. \& Vorster, W.S., eds. Words from afar. Cape Town: Tafelberg. p. 108-118.)

McKANE, W. 1970. Proverbs: a new approach. London: Student Christian Movement Press.

MURPHY, R.E. 1998. Proverbs: word biblical commentary. Vol. 22. Nashville: Nelson.

O'CONNOR, K. 1993. The wisdom literature. Collegeville: Liturgical Press.

PECK, M.S. 1978. The road less travelled. London: Hutchinson.

PECK, M.S. 1985. What return can I make? London: Arrow Books.

PECK, M.S. 1993. A world waiting to be born: the search for civility. London: Random House.

PERDUE, L.G. 1994. Wisdom and creation: the theology of wisdom literature. Nashville: Abingdon.

PERDUE, L.G. 2000. Proverbs: interpretation. Louisville: John Knox. (A Bible commentary for teaching and preaching.)

RAUCH, J. 2005. Reviewing the moral regeneration movement. www.iss.co.za Date of access: 11 Oct. 2006.

VAN EYSEN, B. 2006. Desmond Tutu continues to offer moral guidance. www.mg.co.za Date of access: 6 Oct. 2006.

WHYBRAY, R.N. 1972. The Book of Proverbs. Cambridge: Cambridge University Press.

WHYBRAY, R.N. 1995. The Book of Proverbs: a survey of modern study. Leiden: Brill.

\section{Key concepts:}

father and son

folly

Ma'at

new covenant

sages

wisdom

wise living 


\section{Kernbegrippe:}

dwaasheid

Ma'at (lewe volgens 'n goddelike orde)

nuwe verbond

vader en seun

wyse leefwyse

wysgere

wysheid 
